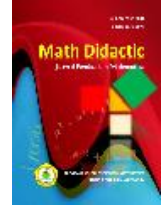

MATH DIDACTIC: JURNAL PENDIDIKAN MATEMATIKA

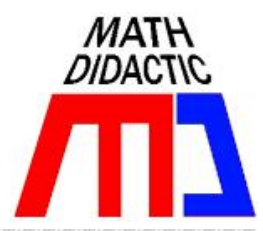

\title{
PENGARUH RASA INGIN TAHU TERHADAP KONEKSI MATEMATIS SISWA PADA PEMBELAJARAN TRIGONOMETRI MENGGUNAKAN MODEL KOOPERATIF TIPE THINK TALK WRITE (TTW) DI KELAS X SMA NEGERI 10 BANJARMASIN TAHUN PELAJARAN 2016-2017
}

\section{THE EFFECT OF WANT TO KNOW ABOUT STUDENT MATHEMATICAL CONNECTION IN TRIGONOMETRY LEARNING USING TTW COOPERATIVE MODEL IN CLASS X SMA NEGERI 10 BANJARMASIN OF ACADEMIC YEAR 2016-2017}

Apriyanto, M. Royani, dan Muh. Fajaruddin Atsnan Pendidikan Matematika STKIP PGRI Banjarmasin apriyanto6767@gmail.com,hmroyanii@gmailcom, ats_krnbangettt@yahoo.co.id

\begin{abstract}
Abstrak: Tujuan penelitian ini adalah untuk mengetahui rasa ingin tahu, kemampuan koneksi matematis, dan ada tidaknya pengaruh rasa ingin tahu terhadap kemampuan koneksi matematis siswa pada pembelajaran trigonometri menggunakan model kooperatif tipe think talk write (TTW) di kelas X-1 SMA Negeri 10 Banjarmasin tahun pelajaran 2016-2017. Metode penelitian menggunakan metode penelitian deskriptif. Populasi adalah siswa kelas X SMA Negeri 10 Banjarmasin tahun pelajaran 2016-2017 yang berjumlah 226 siswa. Teknik pengambilan sampel menggunakan cluster random sampling. Sampel dalam penelian ini adalah siswa kelas X-1 SMA Negeri 10 Banjarmasin yang berjumlah 36 siswa. Teknik pengumpulan data menggunakan observasi dan tes. Hasil penelitian tentang pembelajaran trigonometri menggunakan model kooperatif tipe think talk write (TTW) di kelas X-1 SMA Negeri 10 Banjarmasin menunjukkan bahwa: (1) Karakter rasa ingin tahu siswa termasuk dalam kualifikasi sudah berkembang, (2) Kemampuan koneksi antar konsep matematika siswa termasuk dalam kategori baik, (3) Ada pengaruh karakter rasa ingin tahu terhadap kemampuan koneksi matematis siswa.
\end{abstract}

Kata Kunci: Rasa Ingin Tahu, Koneksi Matematis, Think Talk Write (TTW)

Abstract: The purpose of this study is to know the curiosity, the ability of mathematical connections, and whether or not there is a curiosity influence on students' mathematical connection ability in trigonometry learning using cooperative type think talk write (TTW) model in X-1 class SMA Negeri 10 Banjarmasin school year 2016-2017. The research method using descriptive research method. Population is the students of class X SMA Negeri 10 Banjarmasin year 2016-2017 lessons, amounting to 226 students. The sampling technique used cluster randomsampling. The sample in this study is the students of X-1 class of SMA Negeri 10 Banjarmasin, amounting to 36 students. Technique of collecting data using observation and test. Results of research on trigonometric learning using the think talk write (TTW) cooperative model in class X-1 SMA Negeri 10 Banjarmasin showed that: (1) Character of curiosity of students included in qualification already developed, (2) The ability of connection between mathematical concepts is included in good category, (3) There is influence of curiosity character to students' mathematical connection ability.

Keywords: Want To Know, Mathematical Connection, Think Talk Write (TTW)

Cara Sitasi: Apriyanto, Royani, M., \& Atsnan, M. F. (2018). Pengaruh rasa ingin tahu terhadap koneksi matematis siswa pada pembelajaran trigonometri menggunakan model kooperatif tipe Think Talk Write (TTW) di kelas X SMA Negeri 10 Banjarmasin tahun pelajaran 2016-2017. Math Didactic: Jurnal Pendidikan Matematika, 4(1), 79-87 
Menurut Undang-Undang Republik Indonesia No. 20 Tahun 2003 tentang Sistem Pendidikan Nasional Pasal 3 menyatakan bahwa pendidikan nasional berfungsi mengembangkan kemampuan dan membentuk watak serta peradaban bangsa yang bermartabat dalam rangka mencerdaskan kehidupan bangsa yang bertujuan untuk berkembangnya potensi peserta didik agar menjadi manusia yang beriman dan bertakwa kepada Tuhan Yang Maha Esa, berakhlak mulia, sehat, berilmu, cakap, kreatif, mandiri dan menjadi warga negara yang demokratis serta bertanggung jawab.Untuk mencapai tujuan pendidikan tersebut pemerintah dan pihak swasta bersama-sama membangun jalur pendidikan baik melalui jalur pendidikan formal maupun jalur pendidikan nonformal atau informal. Sekolah merupakan jalur pendidikan formal yang memberikan berbagai macam mata pelajaran salah satunya adalah matematika.

Matematika merupakan bidang studi yang dipelajari oleh semua siswa dari Sekolah Dasar hingga Sekolah Lanjutan Tingkat Atas dan bahkan juga di Perguruan Tinggi (Abdurrahman, 2012: 204). Matematika diberikan secara bertahap dan berjenjang sesuai dengan tahap.

Berdasarkan uraian di atas, peneliti mencoba melakukan penelitian dengan judul "Pengaruh Rasa Ingin Tahu terhadap Koneksi Matematis Siswa pada Pembelajaran Trigonometri Menggunakan Model Kooperatif Tipe Think Talk Write (TTW) Di Kelas X SMA Negeri 10 Banjarmasin Tahun Pelajaran 2016-2017".

\section{Metode Penelitian}

\begin{tabular}{lccr}
\multicolumn{2}{c}{ Penelitian ini } & adalah & penelitian \\
deskriptif & kuantitatif & dengan & menguji \\
hipotesis. & Penelitian & deskriptif & adalah
\end{tabular}

penelitian yang dilakukan untuk menggambarkan atau menjelaskan secara sistematis, faktual, dan akurat mengenai fakta dan sifat populasi tertentu (Nazir, 2014: 43).

Populasi dalam penelitian ini adalah seluruh siswa kelas $\mathrm{X}$ SMA Negeri 10 Banjarmasin tahun pelajaran 2016/2017 yang berjumlah 226 siswa yang tersebar dalam 6 kelas. Keadaan populasi disajikan pada tabel berikut.

Tabel 1. Distribusi Populasi

\begin{tabular}{|c|c|}
\hline Kelas & Jumlah Siswa \\
\hline X-1 & 36 orang \\
\hline X-2 & 38 orang \\
\hline X-3 & 38 orang \\
\hline X-4 & 38 orang \\
\hline X-5 & 38 orang \\
\hline X-6 & 38 orang \\
\hline Jumlah & 226 orang \\
\hline & \\
\hline Teknik & pengambilan \\
\hline
\end{tabular}

menggunakan cluster random sampling, yaitu penarikan sampel dilakukan dengan cara mengundi semua kelas $\mathrm{X}$ yang terdiri dari kelas X-1 sampai X-6 kemudian diambil satu kelas secara acak diperoleh kelas X-1 yang akan dijadikan sebagai sampel penelitian.

Teknik pengumpulan data menggunakan metode observasi dan tes. Observasi digunakan untuk mengamati karakter rasa ingin tahu siswa terutama dalam pembelajaran trigonometri menggunakan model think talk write (TTW), 2 orang observer teman sejawat mahasiswa dan 1 orang guru. Tes digunakan untuk mendapatkan data tertulis berupa hasil jawaban siswa, yaitu 6 soal mengenai materi aturan sinus, kosinus dan luas segitiga untuk melihat kemampuan koneksi antar konsep matematikanya. Data dianalisis menggunakan teknik persentase, rata-rata, dan uji chi-square yang diuraikan sebagai berikut. 


\section{a. Analisis Data Karakter Rasa Ingin Tahu Siswa}

Rasa ingin tahu siswa dihitung dengan menggunakan teknik analisis data persentase dari Sudijono (2010: 43).

$$
\mathrm{P}=\frac{f}{N} \times 100 \%
$$

Keterangan:

$$
\begin{aligned}
P & =\text { Angka persentase } \\
f & =\begin{array}{l}
\text { Frekuensi yang sedang dicari } \\
\text { persentasenya }
\end{array} \\
N & =\begin{array}{l}
\text { Number of Cases (jumlah } \\
\text { frekuensi/banyaknya individu) }
\end{array}
\end{aligned}
$$

Tabel 2. Interpretasi Nilai Karakter

\begin{tabular}{|c|c|}
\hline Nilai (N) & Kualifikasi \\
\hline $80 \leq \mathrm{N} \leq 100$ & Menjadi Kebiasaan \\
\hline $60 \leq \mathrm{N}<80$ & Sudah Berkembang \\
\hline $40 \leq \mathrm{N}<60$ & Mulai Berkembang \\
\hline $20 \leq \mathrm{N}<40$ & Mulai Terlihat \\
\hline$N<20$ & Belum Terlihat \\
\hline
\end{tabular}

( Parmi dan Supinah, 2011: 83)

\section{b. Analisis Data Kemampuan Koneksi Matematis Siswa}

Analisis hasil tes kemampuan koneksi matematika siswa dilakukan dengan cara sebagai berikut.

1. Menghitung skor tiap butir soal dengan acuan pedoman penskoran yang telah ditetapkan. Pedoman penskoran disusun berdasarkan indikator koneksi, yaitu:

a) Kemampuan koneksi antar konsep matematika.

b) Kemampuan koneksi antar konsep dengan ilmu bidang lain.

c) Kemampuan koneksi antar konsep dengan kehidupan sehari-hari.

2. Menjumlahkan perolehan skor siswa.

3. Menghitung nilai kamampuan koneksi per individual dengan menggunakan rumus:

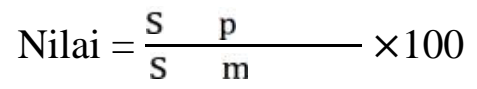

4. Setelah mendapat nilai kemampuan koneksi per individual, kemudian dilakukan pemberian kategori kemampuan koneksi matematis siswa sebagai berikut.

Tabel 3. Kategori Kemampuan Koneksi Matematis

\begin{tabular}{|c|c|}
\hline Nilai $(\mathbf{N})$ & Kategori \\
\hline $85 \leq \mathrm{N} \leq 100$ & Baik Sekali \\
\hline $70 \leq \mathrm{N}<85$ & Baik \\
\hline $60 \leq \mathrm{N}<70$ & Cukup \\
\hline $45 \leq \mathrm{N}<60$ & Kurang \\
\hline $\mathrm{N}<45$ & Kurang Sekali \\
\hline \multicolumn{2}{|c|}{ (Adaptasi dari Arikunto 2012.285) } \\
\hline
\end{tabular}

\section{c. Analisis Data Pengaruh Karakter Rasa Ingin Tahu terhadap Kemampuan Koneksi matematis Siswa}

\section{Data yang diperoleh dari hasil} observasi rasa ingin tahu dan tes kemampuan koneksi matematis siswa berupa hasil lembar jawaban atau langkah-langkah penyelesaian siswa, kemudian dianalisis menggunakan uji chi square untuk mengetahui ada tidaknya pengaruh karakter rasa ingin tahu terhadap kemampuan koneksi matematis siswa. Hipotesis dalam penelitian ini adalah karakter rasa ingin tahu berpengaruh terhadap kemampuan koneksi matematis siswa.

$\chi^{2}=\sum_{i=1}^{b} \sum_{j=1}^{k} \frac{\left(U_{i}-E_{i}\right)^{2}}{E_{i}}$ dengan

$$
E_{i}=\frac{n_{b} \times n_{k}}{n}
$$

Keterangan:

$$
\begin{aligned}
\chi^{2} & =\text { Chi Square } \\
n_{b} & =\text { jumlah baris ke-i } \\
O_{i} & =\text { frekuensi yang diamati } \\
n_{k} & =\text { jumlah kolom ke-i } \\
E_{i} & =\text { frekunsi yang diharapkan } \\
n & =\text { jumlah siswa } \\
\chi_{\text {tabel }}^{2} & =\chi^{2}\left(\begin{array}{ll}
1 & \alpha
\end{array}\right)(\mathrm{dk})
\end{aligned}
$$




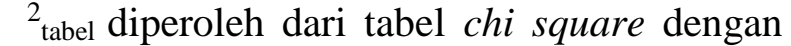
memperhatikan nilai $\chi^{2}$ dimana:

$\alpha=$ taraf signifikansi (5\%)

$\mathrm{dk}=$ derajat kebebasan $(\mathrm{B}-1)(\mathrm{K}-1)$

Dengan ketentuan sebagai berikut.

1. Menguji hipotesis penelitian menggunakan hipotesis statistik sebagai berikut.

tidak ada pengaruh rasa ingin

$H_{U}=$ tahu terhadap kemampuan koneksi matematis siswa. ada pengaruh rasa ingin tahu

$H_{u}=$ terhadap kemampuan koneksi matematis siswa.

2. Kriteria Keputusan

a) Tolak $H_{0}$, jika hanya tolak $H_{0}$

$\chi^{2}$ hitung $\geq \chi_{\text {tabel }}^{2}$

(Nazir, 2014: 362)

\section{Hasil Penelitian dan Pembahasan}

\section{Hasil}

A. Keterlaksanaan Pembelajaran dengan Model Kooperatif Tipe Think Talk Write (TTW)

Pelaksanaan pembelajaran setiap pertemuan berjalan sesuai rencana, yaitu sesuai dengan langkah-langkah pembelajaran menggunakan model tipe think talk write (TTW). Shoimin (2014: 2014-215) menyebutkan langkah-langkah pembelajaran dengan model kooperatif think talk write (TTW) sebagai berikut.

1. Guru mengorganisasikan siswa untuk belajar dengan mengelompokkan siswa menjadi beberapa kelompok dimana tiap kelompok terdiri dari 4-5 orang secara heterogen.
2. Guru memberikan penjelaskan terkait materi yang akan dipelajari, kemudian membagikan lembar kerja kelompok.

3. Siswa membaca lembar kerja kelompok dan membuat catatan kecil (think).

4. Siswa berkerja sama dalam kelompok untuk berdiskusi (talk). Hal ini bertujuan untuk memberikan kesempatan kepada siswa agar terlibat secara aktif dalam berfikir maupun berdiskusi dengan temannya.

5. Siswa menuliskan hasil diskusinya secara individual (write).

6. Beberapa kelompok mempersentasikan hasil diskusi dan kelompok lain memberikan tanggapan dari hasil persentasi.

7. Siswa membuat kesimpulan sesuai materi yang dipelajari.

Semua langkah dalam model kooperatif tipe think talk write (TTW) terlaksana $100 \%$. Hanya saja karena keterbatasan waktu, untuk langkah ke-6 hanya beberapa kelompok yang mempersentasikan hasil diskusi mereka.

\section{B. Rasa Ingin Tahu Siswa}

Rasa ingin tahu siswa diamati tiap pertemuan oleh 3 orang pengamat. Rasa ingin tahu siswa yang diamati lebih kepada rasa ingin tahu siswa yang ada pada langkahlangkah model kooperatif think talk write (TTW), dari 36 siswa yang mengikuti pembelajaran pada saat penelitian dilaksanakan. Hasil persentase rata-rata rasa ingin tahu siswa selama mengikuti proses pembelajaran menggunakan model kooperatif tipe think talk write (TTW), disajikan pada tabel berikut. 
Tabel 4. Rata-Rata Persentase Rasa Ingin Tahu Siswa

\begin{tabular}{|c|c|c|c|c|c|c|c|c|c|}
\hline \multirow{2}{*}{ Aspek yang Diamati } & \multicolumn{3}{|c|}{ Pertemuan 1} & \multicolumn{3}{|c|}{ Pertemuan 2} & \multicolumn{3}{|c|}{ Pertemuan 3} \\
\hline & f & $\%$ & $\mathbf{K}$ & $\mathbf{f}$ & $\%$ & $\mathbf{K}$ & f & $\%$ & \\
\hline $\begin{array}{l}\text { Siswa berdiskusi dengan siswa lain mencari } \\
\text { permasalahan di kehidupan nyata yang bisa } \\
\text { dihubungkan dengan konsep matematika yang } \\
\text { baru dipelajari. }\end{array}$ & 7 & 21,88 & MT & 13 & 40,62 & MB & 15 & 41,67 & MB \\
\hline $\begin{array}{l}\text { Bertanya kepada guru tentang materi } \\
\text { pelajaran yang belum dipahami. }\end{array}$ & 15 & 46,88 & $\mathrm{MB}$ & 20 & 62,50 & SB & 22 & 61,11 & SB \\
\hline $\begin{array}{l}\text { Mengerjakan soal yang diberikan guru dan } \\
\text { mencari tahu penyelesaiannya sendiri. }\end{array}$ & 20 & 62,50 & SB & 25 & 78,13 & MK & 30 & 86,10 & MK \\
\hline $\begin{array}{l}\text { Membaca masalah yang ada dalam LKK dan } \\
\text { membuat catatan kecil pada saat proses } \\
\text { pembelajaran TTW berlangsung. }\end{array}$ & 24 & 75,00 & SB & 30 & 93,75 & MK & 33 & 91,67 & MK \\
\hline $\begin{array}{l}\text { Bekerjasama dengan teman kelompok untuk } \\
\text { membahas hasil catatan kecil dan mencari } \\
\text { penyelesaian masalah. }\end{array}$ & 25 & 78,13 & SB & 27 & 84,38 & MK & 36 & 100 & MK \\
\hline $\begin{array}{l}\text { Bertanya kepada teman sekitar apabila } \\
\text { terdapat sesuatu yang belum dipahami saat } \\
\text { berdiskusi. }\end{array}$ & 21 & 65,60 & SB & 23 & 71,88 & SB & 29 & 83,30 & MK \\
\hline $\begin{array}{l}\text { Ikut berpartisipasi dalam mengerjakan LKK } \\
\text { bersama anggota kelompok }\end{array}$ & 23 & 71,90 & SB & 25 & 78,10 & SB & 33 & 91,67 & MK \\
\hline $\begin{array}{l}\text { Aktif mencari referensi lain (buku } \\
\text { paket/LKS/internet) yang berkaitan dengan } \\
\text { materi pembelajaran. }\end{array}$ & 20 & 62,60 & SB & 22 & 68,78 & SB & 23 & 63,89 & SB \\
\hline $\begin{array}{l}\text { Bertanya kepada teman terhadap hasil } \\
\text { persentasi yang telah dilakukan. }\end{array}$ & 7 & 18,75 & BT & 15 & 46,88 & MB & 18 & 50 & MB \\
\hline Jumlah & 62 & 503,24 & & 200 & 625,02 & $D$ & 239 & 663,87 & \\
\hline Rata-Rata & & 56,25 & MB & & 65,11 & SB & & 74,76 & SB \\
\hline
\end{tabular}

Hasil penelitian menunjukkan bahwa rata-rata persentase karakter rasa ingin tahu siswa mengalami perkembangan di setiap pertemuan. Persentase karakter rasa ingin tahu siswa pada pertemuan pertama rata-rata kualifikasinya mulai terlihat. Berikutnya pada pertemuan kedua rata-rata kualifikasinya mengalami perkembangan beberapa persen dari pertemuan sebelumnya menjadi sudah berkembang. Selanjutnya pertemuan ketiga tidak jauh berbeda dengan pertemuan kedua rata-rata kualifikasinya mengalami perkembangan beberapa persen dan tetap pada kualifikasi sudah berkembang. Hal ini berarti karakter rasa ingin tahu siswa mengalami perkembangan dari mulai terlihat sebesar $56,25 \%$ menjadi sudah berkembang sebesar 74,76\% menggunakan model pembelajaran kooperatif tipe think talk write (TTW). Berikutnya, hasil persentase rasa ingin tahu siswa secara individual disajikan pada tabel berikut. 
Tabel 5. Hasil Persentase Rasa Ingin Tahu Siswa

\begin{tabular}{|c|c|c|c|c|c|c|c|}
\hline \multirow{3}{*}{ Nilai (N) } & \multirow{3}{*}{ Kualifikasi } & \multicolumn{6}{|c|}{ Pertemuan ke } \\
\hline & & \multicolumn{2}{|c|}{1} & \multicolumn{2}{|c|}{2} & \multicolumn{2}{|c|}{3} \\
\hline & & $\mathbf{f}$ & $\%$ & $\mathbf{f}$ & $\%$ & $\mathbf{f}$ & $\%$ \\
\hline $80 \leq N \leq 100$ & Menjadi kebiasan & 2 & 6,25 & 5 & 15.62 & 9 & 25 \\
\hline $60 \leq \mathrm{N}<80$ & Sudah berkembang & 14 & 43,75 & 17 & 53,13 & 21 & 58,33 \\
\hline $40 \leq \mathrm{N}<60$ & Mulai berkembang & 7 & 21,88 & 8 & 25 & 5 & 13,89 \\
\hline $20 \leq \mathrm{N}<40$ & Mulai terlihat & 6 & 18,75 & 2 & 6,25 & 1 & 2,78 \\
\hline $\mathrm{N}<20$ & Belum terlihat & 3 & 9,37 & - & - & - & - \\
\hline \multicolumn{2}{|c|}{ Jumlah } & 32 & 100 & 32 & 100 & 36 & 100 \\
\hline
\end{tabular}

Hasil penelitian menunjukkan bahwa kualifikasi untuk pertemuan pertama sebagian besar sudah berkembang, namun ada beberapa siswa yang masih berada pada kualifikasi mulai terlihat. Pada pertemuan kedua dan ketiga sudah tidak ada lagi siswa yang berada pada kualifiksi belum terlihat. Hal ini, bererti kualifikasi karakter rasa ingin tahu siswa mengalami perkembangan dari $6,25 \%$ menjadi $25 \%$ dengan menggunakan model pembelajaran kooperatif tipe think talk write (TTW).

\section{Kemampuan Koneksi Matematis Siswa}

Kemampuan koneksi matematika siswa diperoleh dari hasil tes berupa jawaban/langkah-langkah penyelesaian soal sebanyak 6 butir soal. National Council of Teacher of Mathematics (NCTM) dalam Linto (2012: 83) yang mengemukakan indikator kemampuan koneksi matematis meliputi: (1) mengenali representasi yang ekuivalen dari suatu konsep yang sama, (2) mengenali hubungan prosedur satu representasi ke prosedur representasi yang ekuivalen, (3) menggunakan dan menilai koneksi beberapa kosep matematika, (4) menggunakan dan menilai koneksi antara matematika dan disiplin ilmu lain. Berdasarkan indikator yang dikemukakan oleh NCTM, maka NCTM mengindikasikan bahwa koneksi matematis terbagi tiga aspek keneksi matematis yang akan menjadi indikator koneksi matematis siswa, yaitu: (1) koneksi antar konsep matematika, (2) koneksi dengan ilmu bidang lain, dan (3) koneksi dengan dunia nyata/dalam kehidupan sehari-hari. Hasil penelitian tentang kemampuan koneksi matematis siswa, disajikan pada tabel berikut.

Tabel 6. Hasil Kategori Kemampuan

Koneksi Matematika

\begin{tabular}{|c|c|c|c|}
\hline \multicolumn{4}{|c|}{ and } \\
\hline Nilai (N) & Kategori & Frekuensi & $\%$ \\
\hline $85 \leq \mathrm{N} \leq 100$ & Sangat Baik & 11 & $30,56 \%$ \\
\hline $70 \leq \mathrm{N}<84$ & Baik & 12 & $33,33 \%$ \\
\hline $60 \leq \mathrm{N}<69$ & Cukup & 5 & $13,89 \%$ \\
\hline $45 \leq \mathrm{N}<59$ & Kurang & 3 & $8,33 \%$ \\
\hline $\mathrm{N}<45$ & Sangat kurang & 5 & $13,89 \%$ \\
\hline & Jumlah & 36 & $100 \%$ \\
\hline
\end{tabular}

Berdasarkan tabel di atas terlihat bahwa, kemampuan koneksi matematis siswa sebagian besar berada pada kategori baik dan sangat baik. Hal ini menunjukkan bahwa proses pembelajaran menggunakan model pembelajaran kooperatif tipe think talk write (TTW) dapat membangun kemampuan koneksi matematis siswa.

\section{Pembahasan}

Berdasarkan hasil analisis uji ChiSquare dapat disimpulkan bahwa ada pengaruh karakter rasa ingin tahu terhadap kemampuan koneksi matematis siswa kelas X1 SMA Negeri 10 Banjarmasin tahun pelajaran 2016-2017. Hal ini, dikarenakan ada salah satu 
faktor yang mendukung adanya pengaruh rasa ingin tahu terhadap kemampuan koneksi matematis siswa, yaitu model pembelajaran kooperatif tipe think talk write (TTW) yang digunakan dalam penelitian ini. Model pembelajaran ini, menuntut siswa terlibat aktif dalam tahap think (berfikir), talk (berbicara/berdiskusi), dan write (menulis). Sehingga siswa menjadi termotivasi mengikuti pelajaran dengan baik yang berakibat pada kemampuan koneksi matematisnya. Pada tahap think (berfikir), siswa dituntut untuk memahami, memikirkan kemungkinan jawaban/model penyelesaian, dan membuat catatan kecil tentang ide-ide yang terdapat pada bacaan. Dalam hal ini, membuat catatan dapat mempertinggi pengetahuan siswa dan meningkatkan kemampuan berfikir dan menulis.

\begin{tabular}{c|c|c} 
Berikutnya & tahap & talk \\
(berbicara/berdiskusi), & siswa & diberi
\end{tabular}
kesempatan berdiskusi untuk menyampaiakan ide-idenya. Didalam diskusi ini terjadi proses interaksi, baik interaksi antar guru dengan siswa maupun antar siswa dengan siswa yang akan mendorong siswa untuk terlibat aktif dalam belajar. Interaksi di antara mereka juga akan menyebabkan munculnya rasa ingin tahu siswa seperti siswa aktif mengajukan pertanyaan, berpartisipasi dengan anggota kelompoknya, dan aktif mencari informasi dari berbagai sumber belajar untuk mencari suatu penyelesaian masalah. Dalam hal ini, rasa ingin tahu siswa sangat ditekankan dalam proses pembelajaran, karena rasa ingin tahu membuat pikiran siswa aktif. Siswa yang pikirannya aktif akan belajar dengan baik, sebagaimana yang dijelaskan teori konstruktivisme, dimana siswa dalam belajar harus secara aktif membangun pengetahuannya (Syamsul, 2013: 148). Dengan demikian, interaksi dapat membangun pemahaman dan pengetahuannya, untuk menyelesaikan masalah yang dihadapi.

Selanjutnya tahap write (menulis), melalui pemahaman dan pengetahuan yang diperoleh, siswa menuliskan hasil diskusinya berupa langkah-langkah penyelesaian. Oleh karena itu, aktivitas menulis akan membantu pemahaman siswa dalam mengkonstruksikan pengetahuannya, sehingga siswa dapat mengkoneksikan/mengaitkan/menghubungka n konsep dalam matematika. Sejalan dengan Shield (dalam Shoimin, 2014: 213) yang menyatakan bahwa aktivitas menulis dapat membantu siswa merealisasikan salah satu tujuan pembelajaran, yaitu pemahaman siswa tentang materi yang dipelajari dan membuat hubungan antar konsep. Dengan demikian, melalui pemahaman dan pengetahuan siswa yang sudah diperoleh selama mengikuti pelajaran, siswa dapat mengkonstrusikan pengetahuannya dengan lebih baik saat mengikuti tes evaluasi.

\section{Kesimpulan}

Berdasarkan hasil penelitian tentang rasa ingin tahu dan kemampuan matematis siswa pada pembelajaran trigonometri menggunakan model pembelajaran kooperatif tipe think talk write (TTW) kelas X-1 SMA Negeri 10 Banjarmasin tahun pelajaran 2016-2017 dapat disimpulkan bahwa:

1) Karakter rasa ingin tahu siswa kelas $X-1$ SMA Negeri 10 Banjarmasin pada pembelajaran trigonometri menggunakan model pembelajaran kooperatif tipe think talk write (TTW) termasuk dalam kualifikasi sudah berkembang.

2) Kemampuan koneksi antarkonsep siswa kelas X-1 SMA Negeri 10 Banjarmasin pada pembelajaran trigonometri menggunakan model pembelajaran 
kooperatif tipe think talk write (TTW) termasuk dalam kategori baik.

3) Ada pengaruh karakter rasa ingin tahu terhadap kemampuan koneksi matematis siswa kelas X-1 SMA Negeri 10 Banjarmasin.

\section{Daftar Pustaka}

Abdurrahman, Mulyono. 2012. Anak Berkepribadian Belajar Teori, Diagnosis, dan Remidiasinya. Jakarta: Rineka Cipta.

Anandita, Gustine Primadya. (2015). Analisis Kemampuan Koneksi Matematis Siswa SMP Kelas VIII pada Materi Kubus dan Balok. Skripsi tidak dipublikasikan. Semarang. Universitas Negeri Semarang. [online] http://lib.unnes.ac.id/21529/1/4101411 075-S.pdf. [14 November 2016].

Ainurrizqiah, Zulfa. 2015. Keefektifan Model PjBL dengan Tugas Creative MindMap untuk Meningkatkan Koneksi Matematika Siswa. Skripsi tidak dipublikasikan. Semarang: Universitas Negeri Semarang. [online]https://www.scribd.com/docu ment/340374092/4101411061-S. [14 November 2016].

Arikunto, Suharsimi. 2010. Prosedur Penelitian suatu Pendekatan Praktik.Jakarta: PT Rineka Cipta.

Arikunto, Suharsimi. 2012. Dasar-Dasar Evaluasi Pendidikan. Jakarta: Bumi Aksara.

Fathani, Abdul Hakim. 2009. Matematika Hakikat dan Logika. Jogjakarta: AR Ruzz Media
Hendriana, Heris dan Soemarmo, Utari. 2014. Penilaian Pembelajaran Matematika. Bandung: Refika Aditama.

Huda, Miftahul. Model-Model Pengajaran dan Pembelajaran: Isu-Isu Metodis dan Paradigmatis. Yogyakarta: Pustaka Pelajar.

Hudojo, Herman. 1988. Mengajar Belajar Matematika. Jakarta: Proyek Pengembangan Lembaga Pendidikan Tenaga Kependidikan.

Hamdayama, Jumanta. 2014. Model dan Metode Pembelajaran Kreatif dan Berkarakter. Bogor. Ghalia Indonesia.

Kemendiknas. 2010. Undang-Undang Republik Indonesia Nomer 20 Tahun 2003 tentang Sistem Pendidikan Nasional 2013. Jakarta: Sinar Grafika.

Kemendiknas. 2011. Pengembangan Pendidikan Karakter dan Budaya Bangsa. Jakarta: Kemendiknas.

Kunandar. 2013. Penilaian Autentik (Penilaian Hasil Belajar Peserta Didik Berdasarkan Kurikulum 2013) Suatu Pendekatan Praktis. Jakarta: Raja Grafino Persada.

Kurniawan, Syamsul. 2013. Pendidikan Karakter: Konsepsi \& Implementasi Secara Terpadu Di Lingkungan Keluarga, Sekolah, Perguruan Tinggi \& Masyarakat. Yogyakarta : AR Ruzz Media.

Linto, Rendya Logina, dkk. 2012. Kemampuan Koneksi Matematis dan Metode Pembalajaran Quantum Tiching dengan Peta Konsep. Jurnal Pendidikan Matematika. 1 (1): 83-87. 
Listyarti, Retno. 2012. Pendidikan Karakter dalam Metode Aktif, Inovatif dan Kreatif. Jakarta: Erlangga.

Nazir, Moh. 2014. Metode Penelitian. Jakarta: Ghalia Indonesia.

Parmi, I.T dan Supinah. 2011. Pengembangan Pendidikan Budaya Dan Karakter Bangsa melalui Pembelajaran Matematika di SD. Kemendiknas.

Permana, Yanto dan Sumarmo, Utari. 2007. Mengembangkan Kemampuan Penalaran dan Koneksi Matematik Siswa SMA Melalui Pembelajaran Berbasis Masalah. Jurnal Educationist, 1(2), 117.

Riduwan. 2010.Belajar Mudah Penelitian untuk Guru-Karyawan dan Peneliti Pemula. Bandung: Alfabeta

Rusman. 2012. Model-Model Pembelajaran Mengembangkan Profesionalisme Guru. Jakarta: PT. Raja Grafindo Persada.

Sanjaya, Wina. Strategi Pembelajaran Berorientasi Standar Proses Pendidikan. Jakarta: Kencana Prenada Media Group.

Setiawan, Andri. 2010. Pengaruh Strategi Berhitung (Different Strategies) terhadap Hasil Belajar Matematika Siswa pada Materi Operasi Bilangan Bulat. Skripsi tidak dipublikasikan. Jakarta. Universitas Islam Negeri Syarif Hidayatullah Jakarta. [online] http://repository.uinjkt.ac.id/dspace/bit stream/123456789/2685/1/ANDRI\%2 OSETIAWAN-FITK.pdf. November 2016].

Shadiq, Fadjar. 2014. Pembelajaran Matematika: Cara Meningkatkan
Kemampuan Berpikir Kritis. Yogyakarta: Graha Ilmu.

Shoimin, Aris. 2014. 68 Model Pembelajaran Inovatif dalam Kurikulum 2013. Yogyakarta: Ar-Ruzz Media.

Sudijono, Anas. 2010. Pengantar Statistika Pendidikan. Jakarta: Rajawali Pres.

Sugiyono. 2015. Metode Penelitian Kombinasi (Mixed Methods). Bandung: Alfabeta, $\mathrm{CV}$.

Suriansyah, Ahmad. 2011. Landasan Pendidikan. Banjarmasin: Comdes.

Sutikno, M. Sobry. 2009. Belajar dan Pembelajaran "Upaya Kreatif dalam Mewujudkan Pembelajaran yang Berhasil”. Bandung: Prospect

Tim Penyusun. 2016. Pedoman Penulisan Skripsi. Banjarmasin: STKIP PGRI Banjarmasin.

Trianto. 2014. Mendesain Model Pembelajaran Inovatif-Progresif. Jakarta: Kencana. 